\title{
A "Voice to Sing": Rongelapese Musical Activism and the Production of Nuclear Knowledge
}

\section{JESSICA A. SCHWARTZ}

Based on two years of ethnographic work (2008-2010) in the Republic of the Marshall Islands (RMI), I present my work with a tight-knit community of Rongelapese women residing in Majuro Atoll, whose music yields insight into the role of expressive culture in mitigating the damages of a nuclear legacy, at various scales, that has often played out in secrecy and silence (Fig. 1). ${ }^{1}$ The Rongelapese women's musical activism, I argue following Jacques Rancière, generates dissensus, or "the essence of politics... [as] the demonstration (manifestation) of a gap in the sensible itself." ${ }^{2}$ Framed within the nuclear context and rooted in an exploration of the particularities of culturally meaningful practices, conceptions of the body/senses, and notions of the political, I trace how Rongelapese women's vocality and musicality responds locally to the global phenomenon of nuclear silences (as gaps in our present day nuclear knowledge) by making indistinguishable questions of health, politics, and generational survival as felt and thought. ${ }^{3}$

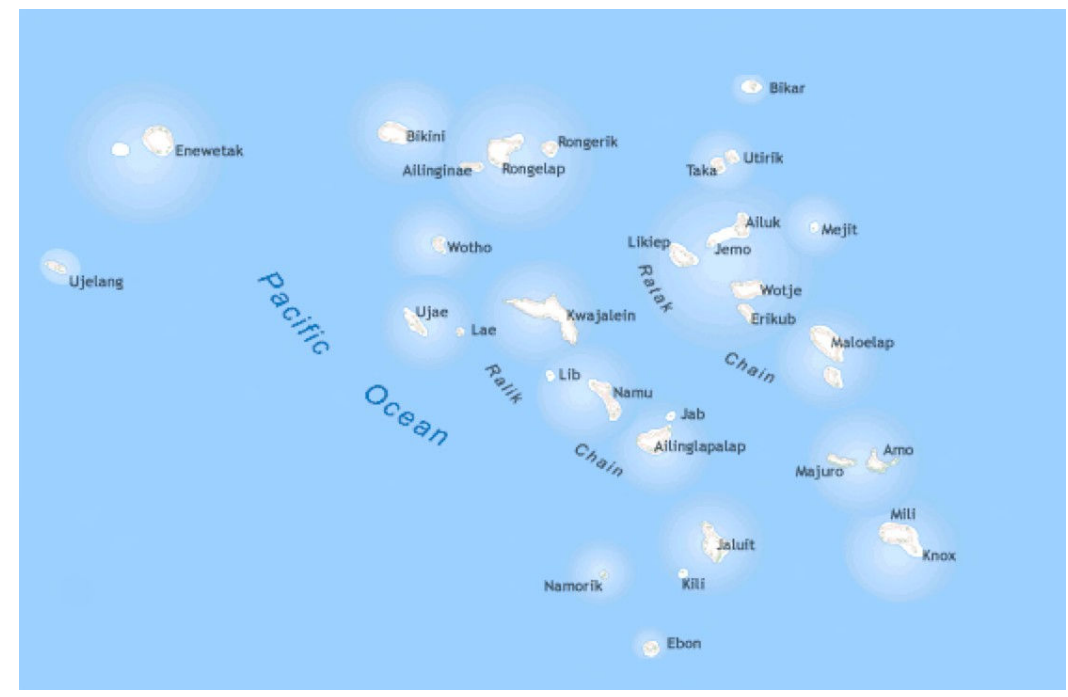

Figure 1. Map of the Republic of the Marshall Islands.

\footnotetext{
${ }^{1}$ The Marshall Islands are a Pacific archipelago of twenty-nine atolls and five islands that comprise two island chains (Ratak and Rālik). I refer to individuals as both Marshallese (ethnicity/nationality) and in accordance with how people often refer to their identities (belonging to an atoll, e.g. Bikinian, Rongelapese). The primary and official language is Marshallese, an Autronesian language. There are approximately 60,000 people living in the Marshall Islands, and the capital city/atoll Majuro Atoll has a population of about 25,500. It is the most populous city. The Rongelapese, the population focused on in this article, number in the few hundreds. The United States conducted sixty-seven nuclear tests in the archipelago from 1946 through 1958.

2 Jacques Rancière, Dissensus: Politics and Aesthetics, trans. Steven Corcoran (New York: Continuum, 2010$), 38$.

${ }^{3}$ These examples are part of a large repertoire that has emerged over the last sixty-five years that responds to the deleterious effects of nuclear weaponry and US militarism that pervade everyday life in the Marshall Islands.
} 
The Rongelapese, at this moment, are in flux, and they live in Mejato Island (Kwajalein Atoll), Majuro Atoll, and various locations in the United States (Video 1).

Video Example 1: Temporary residences of the Rongelapese

View at: http://dx.doi.org/10.3998/mp.9460447.0006.101

At the time of writing this article (2012), some Rongelapese are preparing to move back to Rongelap, "but national government leaders have raised questions about the safety of the entire atoll because the cleanup work has only focused on the main island, not the more than sixty other islands at Rongelap. In addition, Rongelapese elders...have questioned the safety of the atoll." 4 They have been displaced from their homeland since 1985 and, informed by the silent spaces at the end of these questions concerning safety and many other questions, the Rongelapese will remain displaced and disenfranchised for the foreseeable future.

\section{A Dream and a Song 5}

On the eve of her eighth birthday, a Marshallese girl from the northern atoll of Rongelap stayed on Jelaen Island in Ailingane Atoll with her grandmother and a couple of other people. As she slept, she had a vivid dream. The girl was in a field, and airplanes were pummeling her environment with bombs. The dream was so real that she could hear the sound of the planes. In the field, there was a ring of fire, and it encircled her. Suddenly, her world was awash with a bright flash, which was followed by a powerful rumble and deep roar. Then, the ground began to shake ferociously and a heavy wind blasted through the atoll blanketing the island with granular material. A few other people staying on a different island in the atoll came to Jelaen Island to get water. They said the water around their island was turning violet. Everyone went to the beach, and together they looked westward. And to their shock, they saw a billowing cloud increasing in size and expanding over the Pacific Ocean from its location at Bikini Atoll. Everyone was gripped with an intense terror because they had not heard anything from anyone about the event.

The girl's grandmother grasped for an explanation. Perhaps it was the beginning of World War III. Perhaps they should hide. Just as morning turned to afternoon, the heavy winds carried more debris, and it covered the girl's birthday lunch, which the family had to wash off with salt water. Some indiscernible amount of time later an American battleship came to evacuate the people from Ailingnae Atoll. The girl and one other person were so scared that they hid. The Americans urged them to board the ship and persuaded them with promises: "We won't hurt you." Everyone boarded the ship. They were forced to leave all their personal belongings behind. All they took were the articles of clothing on their backs, which were removed and thrown into the water once they boarded the ship. Thirty-one years later, when the girl was a woman of almost forty years, she returned to the island to say "goodbye" before she left its familiar terrain for the last time.

\footnotetext{
${ }^{4}$ Giff Johnson, "Rongelap return could happen in near future," RimajolOnline, last modified March 26, 2012, http://www.rimajol.com/forums/viewtopic.php?t=5219.

${ }^{5}$ Based on: Lijon MacDonald, interview with author, October, 2009.
} 
And today, she says:

Having suffered multiple losses when bearing children, having uncontrolled weight fluctuations, having memory loss and tight curling fingers, having nearly lost my voice, I can say that nothing is more important than having my health and my voice to sing. ${ }^{6}$

After the initial flash, the dream became reality, explains Lijon MacDonald, a prolific composer, selfproclaimed politician ("in a good way"), and anti-nuclear activist. She sits on her bed in her house in Majuro Atoll, picks up an acoustic guitar, and places her fingers on the first and second frets in the position of an open C-major chord. She looks thoughtfully at the guitar as she slowly arpeggiates the chord, making sure the guitar is in tune:

I composed this song by myself because of the time I would sit and spend time contemplating the bomb. I realized there needed to be a song about the bombs dropped on Bikini and Enewetak, because it is something I grew up with. I used to dream at night about the bomb, and in my dreams I would see the bomb drop on an island, and I would be the only one standing, with all the fire, and there weren't any people, and so I would be scared. I would awaken and cry because I was so scared, and I'd wake up because the flash of the bomb hurt my eyes. I would cry so much, and that is the reason I wrote this song. ${ }^{7}$

She repeats the musical gesture two times and steadily launches into a rhythm in six-eight meter, at a moderate tempo, for two measures. At the third measure, Lijon sings the first verse.

\author{
Juon jọtiinin iar kiki \\ im ettōñake ijo jiku im āo lamoren \\ Eo rej ṇa etan Jelaen Aelōñ, \\ juon āne emakelok \\ Aelōñ in Bikini Atoll,
}

\author{
One night I was sleeping \\ on the porch of my place, of my homeland \\ They call it Jelaen Island, \\ it's an isolated island near \\ The atoll of "Bikini Atoll"
}

Her voice, injured by thyroid surgery and changing with age, cracks slightly on the word, "juon." As she continues to sing and strum the guitar, she encounters moments of hoarseness and vocal instability. Lijon pushes through the grainy timbre that results in a soft vocal waiver. As she sings the refrain twice, this dynamic shapes the song, which to my ear sounds reminiscent of a lullaby.

Ilo Maaj juon raan in 'fifty-four
Juon mejatoto enana
Elap jorrān ear walok
Iar ilbōk im ruj kōn aō jañ
Iar jab loe maan kōn dānnin kōmjaalal

Ilo Maaj juon raan in 'fifty-four

Juon mejatoto enana

Iar ilbōk im ruj kōn aō jã̃ 
timbre, she endeavors, and ultimately succeeds, in transforming the inflected register to a sweet, airy, almost ephemeral tone. We hear, in these moments, the physical labor that goes into the musical work of sustaining a voice worth hearing and, by extension, memories and lives worth saving. Lijon repeats the chorus and sings the second verse:

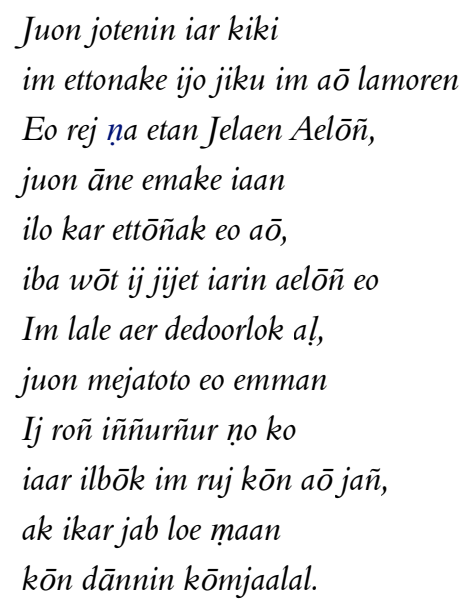

Juon jotenin iar kiki

im ettonake ijo jiku im aō lamoren

Eo rej ṇa etan Jelaen Aelō̃̃

jun àne emake iaan

iba wōt ij jijet iarin aelōñ eo

oorlok al

\author{
One night I was sleeping \\ on the porch of my place, of my homeland \\ They call it Jelaen Island, \\ it's a very isolated place \\ On my porch, \\ I was sitting on the lagoon side of the island, \\ and I saw a sunset, \\ a good atmosphere \\ I heard the murmuring of the waves \\ I was startled and I woke up crying, \\ but I couldn't see clearly (look forward) \\ because of my tears.
}

Lijon composed the song at two different times for the same reason: to remember her homeland, and as such, the song is an al in keememej (remembrance song). The first verse and chorus were composed in 2004, the $50^{\text {th }}$ anniversary of the powerful thermonuclear test, Castle Bravo, which irradiated Lijon's islands and the population. The second verse was composed "a long time ago" when Lijon was living on Ebeye Island in Kwajalein Atoll. Lijon says the song is a juxtaposition between the beauty of Jelaen Island (literally "knowledge of" or "known of") and everything else that has taken place with regards to the bomb. "Everything else" (the silence and terror of being consumed by not knowing and not feeling that which animates) is in contrast to (knowledge/feeling of the animate, sentient landscape) her place (which is her land, lineage, epistemic access to her culture). The song is a recuperation, therefore, of two types of memory, or, following C. Nadia Seremetakis, memory as "meta-sense." ${ }^{8}$ With the introduction of the first verse and chorus as preface, Lijon creates a world of dissensus from words that articulate a lack of clarity in the metaphor of the "tear," the material produced from internalized emotional tension through the mechanism of crying that creates "lumps" in the throat, rendering one speechless or inarticulate. The lack of clarity, or "what cannot be assimilated[,] crystalizes around a date": March 1, 1954. ${ }^{9}$

Lijon sings "year" and "month" in English, and these words are part of what anthropologist Holly M. Barker has detailed as her interlocutors' "unique, highly situational, and localized radiation language [constructed] almost entirely with Marshallese words." ${ }^{10}$ Following Barker, I first provide a history of nuclear silences as the contextual "gap" that the Rongelapese women endeavor to make audible. I then provide examples of a new subgenre of al in keememeej (remembrance songs)—what I term "radiation songs" - in the ceremonial performances that structure the work of mourning by dating it (March 1, 1954) and making sensible its resonant, historically contingent silences precisely as inscribed in the listening subject (and therefore capable of being vocalized).

\footnotetext{
${ }^{8}$ C. Nadia Seremetakis, ed., The Senses Still: Perception and Memory as Material Culture in Modernity (Chicago: University of Chicago Press, 1996), 9.

${ }^{9}$ Shoshana Felman, "Benjamin's Silence," Critical Inquiry 25, no. 2 (1999): 206.

${ }^{10}$ Holly M. Barker, Bravo for the Marshallese (Belmont, CA: Wadsworth, 2004), 83.
} 


\section{Nuclear Silences}

Throughout this article, I refer to nuclear silences as metaphorical, regulatory, and actual, although it is important to consider the interrelatedness of the three broad categories. Metaphorical silences are those silences that are, for example, symbolic of regulatory and actual silences, the traumatic internalizationsand therefore incommunicable dimensions-of nuclear damages and rhetorical silences, such as the pregnant pauses throughout an interrogation. These silences manifest as expressive "non-sense" or "noises" that disrupt the law (language). Regulatory silences are the laws that restrict, or prohibit, speech and enforce policies of isolation. These juridical and political matters that control information also control bodies-not just what they can say but with whom they can talk and where they can go, for example. The actual, or physical and material, silences of which I speak are the sounds on an island vaporized or the voice of a person deceased. If metaphorical silences are symbolic or expressive of regulatory and actual silences, how much stock do we put into the latter terms as absolute? In other words, what pressure do the particular experiences of sonorously manifested silence put on the universal law/language of "human rights" as part of contested sensibilities? Wherein might an ethics of listening in the nuclear age serve to straddle, or muddy, the divide between culture and nature, or censorship and absence/absolute silence as a "natural phenomenon"?

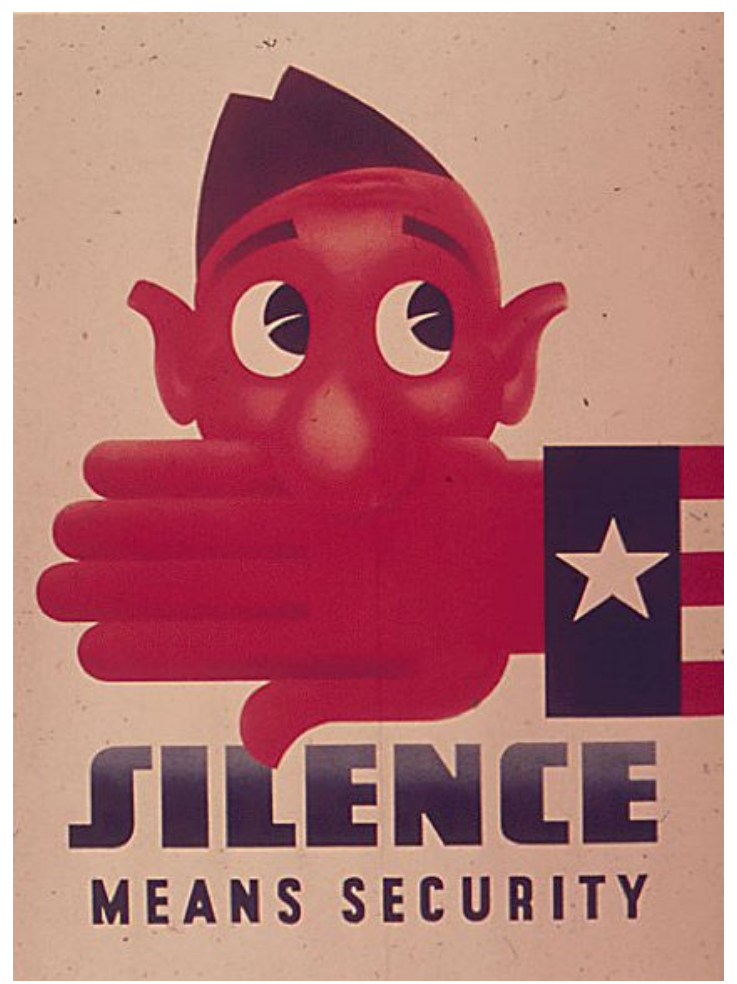

Figure 2. "Silence Means Security," c. 1943. Originally produced by the Office for Emergency Management via the Bureau of Special Services of the Office of War Information. (Records of the Office of Government Reports, 1932-1947, Still Picture Records Section, Special Media Archives Services Division at Archives II in College Park, Maryland.) 
"Silence means security" was an American slogan coined during World War II as the nation began to formulate its role as a world power (Fig. 2). During this period of time, atomic weaponry was being developed in a top-secret milieu. With the Manhattan project and consequent Cold War, national security was even more linked with an administration with a domestic and foreign policy characterized by secrecy. The United States government developed a complex "secrecy system," based on work done by notable wartime theorists such as Claude Shannon, the author of "Communications Theory of Secrecy Systems," to withhold from the American public and foreign adversaries information about the magnitude of the atomic bomb's destructive capabilities. ${ }^{11}$ Much of the information guarded at a global level came from the tests in the Marshall Islands.

Lijon, barely eight years old at the time, was just seventy-five miles southeast from the location of the detonation of the largest thermonuclear weapon in US history, "Castle Bravo" ("Bravo"), that occurred on March 1, 1954. The stunning visual display Lijon and her family witnessed was caused by Bravo's radioactive mushroom cloud that rose to 130,000 feet and spread in diameter over sixty-two square miles in under ten minutes, expanding to over 7,000 square miles. ${ }^{12}$ As the cloud plumed higher into the atmosphere, a shockwave and resonant boom prompted screams from frightened children on Rongelap. Molly, a Rongelapese woman who was fourteen years old at the time, told me of people who were terrified by the "loud sound [that] shook the ground" and caused the thatched houses to shake. ${ }^{13}$ Later that day, the wind carried irradiated coral dust from a completely vaporized island at Bikini Atoll to the east and covered the atolls of Rongelap, Ailingnae, and Rongerik (Video 2). ${ }^{14}$

Video Example 2: Fallout pattern

View at: http://dx.doi.org/10.3998/mp.9460447.0006.101

Children played in the fallout because they thought it was snow. ${ }^{15}$ They "tasted it" and "rubbed it in their eyes." ${ }^{" 16}$ Women used the white flakes as shampoo until their scalps burned and their hair fell out in large chunks. Men, women, and children became violently ill and ran into the lagoon for respite, but they could

\footnotetext{
${ }^{11}$ Claude Shannon. "Communication Theory of Secrecy Systems," in Bell Systems Technical fournal 28, no. 4 (1949): 656-715. For more information on policies of secrecy during the atomic age, see Laura McEnaney, Militarization Meets Everyday Life in the Fifties (Princeton and Oxford: Princeton University Press, 2000).

${ }^{12}$ As a point of reference, New Jersey is 8,722 square miles and Connecticut is 5,544 square miles. Information from "US States: Area and Ranking," Enchanted Learning.com, http://www.enchantedlearning.com/usa/states/area.shtml.

${ }^{13}$ Molly (Rongelapese woman), interview with author, March 20, 2010. Name changed at interlocutor's request.

${ }^{14}$ 1) Three of Bikini Atoll's islands were vaporized due to the nuclear testing: Bokonijien, Aerokojlol, and Nam. 2) When I refer to Rongelap as land that is uninhabitable, the atolls of Ailingnae and Rongerik are included. I follow Holly M. Barker and Barbara Rose Johnston, Consequential Damages of Nuclear War: The Rongelap Report (Walnut Creek, CA: Left Coast Press, Inc., 2008) and stress that in this article, “'the people of Rongelap,' or 'Rongelapese,' refers to those people exiled from Rongelap, Rongerik, and Ailinginae atolls. They are typically considered by other Marshallese as a single sociopolitical unit and they are represented in the RMI government by one elected senator, although members of the Rongelap community retain rights to three atolls," 43.

${ }^{15}$ Castle Bravo, the codename of the thermonuclear test conducted on March 1, 1954, was one thousand times more powerful than the first atomic tests in 1946, and it came as a shock to many that the Rongelapese had not been evacuated before the unprecedented test. The three islands vaporized at Bikini Atoll were turned into the "fallout" that covered Rongelap and other atolls in the Marshall Islands. It was then that the term "fallout" was introduced into our lexicon. While I mention Utrik, I focus on the population of Rongelap. For more information on Utrik and the population of Utrik, see, Glenn H. Alcalay, "Utrik Atoll: The Sociocultural Impact of Living in a Radioactive Environment (An Anthropological Assessment of the Consequential Damages from Bravo)," June 28, 2002. The report was prepared at the request of the Utrik Atoll Local Government and the Office of the Public Advocate, Nuclear Claims Tribunal, Majuro, RMI.

${ }^{16}$ Molly (Rongelapese woman), interview with author, March 20, 2010. Name of interlocutor changed at her request.
} 
not sense it was dangerously radioactive. ${ }^{17}$

The confusion of the islanders only grew as Americans came to survey the islands and departed without giving the residents clear directions or explanations in regards to the unusual event. John Anjain, the Rongelapese magistrate, stated that by the afternoon of March 2, 1954 (thirty-six hours after the explosion), two American officials came to Rongelap "to inspect the damage done by the bomb," but in their short survey that lasted less than an hour, "they left without telling anyone that the food, water, and other things were harmful to human beings." ${ }^{18}$ Forty-eight hours after the initial explosion, after much fear and bewilderment, the United States military came with a ship and seaplane to evacuate the 236 Rongelapese. Scared, humiliated, and sick with radiation poisoning, the Rongelapese followed the Americans onto a naval ship.

\section{Restricting Voices as Data}

The Atomic Energy Act of 1946, signed into law by President Harry S. Truman exactly one month after the US began its nuclear testing program at Bikini Atoll, is replete with new terms and provisions that stress and reinforce the correlation of security with secrecy. It defined a new legal term, "restricted data," that made any utterance, mention, or rumor of restricted data until its declassification a violation of the law. The law that restricts free speech continues to be enforced today. In fact, there have been documents recently declassified, but even some of these documents remain only partially declassified.

One example is a collection of documents that were partially declassified during the Clinton Administration that show how Marshallese were used as long-term human subjects by the Atomic Energy Commission (AEC) to derive pertinent information on the human effects of exposure to radiation that resulted from the Bravo test (Fig. 3). ${ }^{19}$ Project 4.1, the Study of Response of Human Beings Exposed to Significant Beta and Gamma Radiation Due to Fallout from High Yield Weapons, was sanctioned under the Atomic Energy Act, and therefore the lands and bodies of the Rongelapese were classified information, or secret "restricted data." ${ }^{20}$ Under Project 4.1, Rongelapese, Utrikese, and other Marshallese in variable groups were numbered and studied both in the Marshall Islands and laboratories in the United States, such as the Brookhaven National Laboratory in Long Island, New York. ${ }^{21}$

On April 20, 1954, the Marshallese decided to take direct action, and they filed a complaint to the United Nations that addressed the socio-cultural, physiological, and psychological problems plaguing the entirety of Marshallese society in hopes of placing a ban on the testing of nuclear weapons in the Marshall

\footnotetext{
${ }^{17}$ Adult intake of radiation solely from the Bravo event was estimated at approximately 300-375 roentgens (whole-body dose), 10,000-20,000 rads (thyroid), and 20-300 rem (internal doses, other than thyroid). Compare with the "current known health effects of ionizing radiation" that places lethal doses at 400 rem (“can kill 50 percent of exposed population"). Information from Barker and Johnston, The Rongelap Report, 97.

${ }^{18}$ Barker and Johnston, The Rongelap Report, 12. The authors quote "excerpts from John Anjain," in "The Fallout on Rongelap Atoll and Its Social, Medical and Environmental Effects," ed. and trans. Richard A. Sundt (unpublished manuscript, 1973), on file at the Nuclear Claims Tribunal, Majuro, RMI. Also, author's interviews with Rongelapese present at the time of the detonation.

${ }^{19}$ For comprehensive information on Project 4.1, refer to Barker and Johnston, The Rongelap Report.

${ }^{20}$ Name of interlocutor has been changed at her request.

${ }^{21}$ Two films address Project 4.1 and the legally sanctioned silence under which it functioned. See, Newsday's "Fallout: Brookhaven's National Lab's Legacy in the Pacific" directed by Thomas Maier and John Paraskevas (Newsday, 2009). And "Nuclear Savage: The Islands of Secret Project 4.1," directed by Adam Jonas Horowitz (Primordial Soup/Equatorial Films, 2012).
} 
Islands. ${ }^{22}$ The United States issued a public statement of "deep regret" on behalf of the American government and people, but with the promise to take care of the Marshallese, nuclear testing was allowed to continue. The publicity of the complaint and international concerns led the United States to increase censorship of the occurrences taking place at the Pacific Proving Grounds.

In June 1954, the Rongelapese were relocated to Ejit Island in Majuro Atoll, the capital. Doctors from the AEC would make regular visits to monitor the populations. ${ }^{23}$ In 1957, one year after the AEC deemed the Marshall Islands to be "by far the most contaminated place in the world," the Rongelapese, who were unaware of the AEC report and "assured their island was safe by Brookhaven doctors," retuned to their homeland because "Brookhaven viewed their homecoming as an opportunity to study radiation on the human body" and "the most valuable ecological data on human beings." ${ }^{24}$ In 1958, President Eisenhower declared a nuclear testing moratorium. Over the course of this twelve-year nuclear testing program, sixty-seven nuclear weapons had been detonated at the Pacific Proving Grounds, the official name given to the sites of the nuclear tests in the Marshall Islands. According to Dr. Neal Palafox from the University of Hawaii, “The testing was almost all done above ground... and the yield was equal to 7,200 Hiroshima bombs. That is like exploding 1.6 Hiroshima bombs a day for 12 years in the Marshall Islands. That's how much radiation there was." ${ }^{25}$

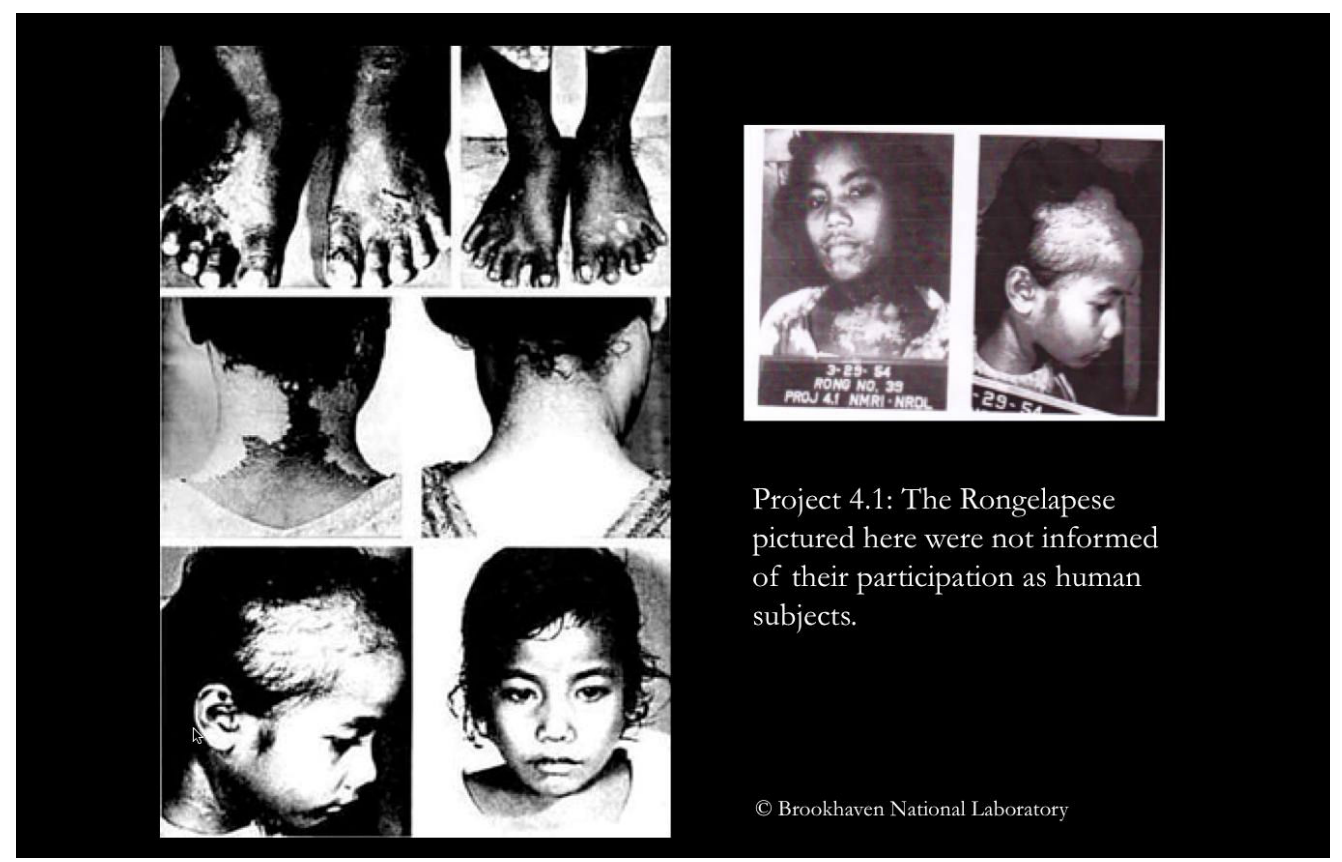

Figure 3. Project 4.1.

\footnotetext{
22 "Petition from the Marshallese People Concerning the Pacific Islands," April 20, 1954 as circulated to the UN Trusteeship Council T/PET.10/28, May 6, 1954 in Barton C. Hacker, Elements of Controversy: The Atomic Energy Commission and Radiation Safety in Nuclear Weapons Testing 1947-1974 (Berkeley and Los Angeles: University of California Press, 1994), 357.

${ }^{23}$ The Rongelapese community's evacuations are part of a larger network of upheavals and displacements to which various communities in the Marshallese were subject throughout the testing program.

${ }^{24}$ Stephanie Cooke, In Mortal Hands: A Cautionary History of the Nuclear Age, (Collingwood, VIC, Australia: Black Inc. Books, 2009), 168.

${ }^{25}$ Dr. Neal Palafox is quoted in Reducing Environmental Risk: What Can We Do Now? The President's Cancer Panel Annual Report 2008-2009, ed. Susan H. Reuben for The President's Cancer Panel (Washington D.C.: U.S. Department of Health and Human Services, April 2010), 114.
} 
"One of the most insidious aspects of radiation," Nuclear Claims Tribunal Public Advocate Bill Graham states as he looks into the camera with a fierce conviction during the filming of Newsday's Fallout: Brookhaven National Lab's Legacy in the Pacific, "is that you can't see it; you can't taste it; you can't touch it. It's there. It affects you in ways that aren't immediately apparent, and that was the environment..." Graham, an American committed to the Marshall Islands for decades, trails off before he can finish his thought. He continues:

You know... [laughs in bewildered disgust and reads from a document] 'The levels of activity are higher than those found in other inhabited locations in the world,' and we are putting you into that environment, into that location so we can see how the radioactivity moves from the soil though the food and into your bodies. Of course [the Rongelapese] weren't being told that, but eventually, they began to get a clue because the doctors kept coming every year. ${ }^{26}$

The American doctors that came every year relied on machines-such as the Geiger countermedical and scientific terms, and often invasive medical procedures to make the insensible radiation and its aftereffects sensible. The doctors listened for and thus heard the sounds as data, but the Rongelapese listened for these sounds to make meaning of their painful situation. ${ }^{27}$ One woman recalled her experiences at the US military base on Kwajalein Atoll while testifying in front of the Nuclear Claims Tribunal:

In front of [the male Rongelapese translators] . . . , three times a day for three months, the Rongelapese women were told to undress and stand naked at the lagoon's edge. The women would cry from embarrassment and try to cover their genitals with their hands. US Government officials, all men, ran Geiger counters up and down the bodies of the naked women both before and after they bathed in the lagoon. Frequently, the Geiger counters would start clicking wildly when taking readings from the hair on the women's heads and from their pubic hair. The US Government workers would tell the women to soap their pubic hair again, in front of everyone, before a second reading. [The male translators] . . . tried to avert their eyes whenever possible but their presence by their naked mothers and sisters was mortifying. ${ }^{28}$

This quote demonstrates a significant difference in gendered experiences of the nuclear encounter. ${ }^{29}$ For women in this context, listening anew became aligned with taboo cultural practices and shameful engagements over which they had no control. The sound of the Geiger counter clicking wildly attuned the Rongelapese to an invisible, insensible poison that had been absorbed by their bodies and manifested as

\footnotetext{
${ }^{26}$ Video of Chapter 1, "No One Lives Here Anymore" from Fallout, http://thyroid-treatments.com/chp-1-newsdays-falloutbrookhaven-national-labs-legacy-in-the-pacific-chapter-1-of-nine/. By 1985, the Rongelapese had made a number of requests to the US government to help them relocate from their irradiated atoll, but the US government refused to provide the funds needed to relocate. After a formal request in 1983 and two years without a response, the Rongelapese solicited the help of Greenpeace's crew and boat, "the Rainbow Warrior." The Rainbow Warrior helped them move to Mejato in Kwajalein Atoll. 27 "If 'to hear' is to understand the sense (either in the so-called figurative sense, or in the so-called proper sense): to hear a siren, a bird, or a drum is already each time to understand at least the rough outline of a situation, a context if not a text), to listen is to be straining toward a possible meaning, and consequently one that is not immediately accessible.” Jean-Luc Nancy makes the distinction between hearing and listening in Listening, trans. Charlott Mandell, (New York: Fordham University Press, 2007), 6.

28 “Claimants exhibit C-1, pp. 21 - 22." From Nuclear Claims Tribunal. Memorandum of Decision and Order (Majuro, Republic of the Marshall Islands, April 17, 2001), accessed 18 February 2011, http://www.nuclearclaimstribunal.com/rongelapfin.htm.

${ }^{29}$ For the ways in which the atomic bombings on Hiroshima and Nagasaki affected women, see Maya Todeschini, "The Bomb's Womb? Women and the Atom Bomb," in Remaking a World: Violence, Social Suffering, and Recovery, ed, Veena Das et al., 102-56.
} 
illness - and yet it sonorized a private experience of the irradiated female body for the public soundscape of American male doctors. ${ }^{30}$

The Rongelapese heard these doctors and scientists speaking in English about the "bomb" (baam) "radiation," "thyroid" (tyroit) "cancer," "poison" (baijin is the Marshallese word for poison, or fallout), and "computers" (computa is the Marshallese word for the Geiger Counter). While the Rongelapese experienced enforced silences that could not accommodate their personal suffering, or what David Morris terms "the irreducible otherness of suffering" as the "nonverbal dimension of suffering that can never be put into words," they nevertheless struggled to learn this new vocabulary to make some sense of and articulate to the best of their ability their suffering, both physical and psychological. ${ }^{31}$

Vocal articulation of this suffering became increasingly difficult as the majority of the women, who were more susceptible to thyroid cancer and disease than men, had a number of operations on their thyroids, which sometimes involved removal of the thyroid. ${ }^{32}$ The surgeries affected their voices, especially because of the vulnerability of the vocal folds exposed to repeat thyroid surgeries. ${ }^{33}$ Some became temporarily mute, others would refrain from speaking, and more specifically, singing, from fear of hearing their altered voices. As women have remarked, they hear themselves differently now, they hear themselves as ribaam-bombed people-employing the term that had been used by members of other Marshallese communities to delineate populations and persons with complications from radiation poison. Initially, Marshallese feared radiation illnesses were contagious, and they would listen to the voices of Rongelapese women for pronounced hoarseness or lowered voices to ascertain whether they were "thyroid," or irradiated:

We used to love singing!...Personally, I don't sing in public anymore because people stare at me. It's like we're in a constant state of puberty where our voices keep cracking. ${ }^{34}$

After the bomb, we can't harmonize anymore. Everyone's voice is a bass, and there are no more sopranos amongst us. We have no interest in singing anymore. People make fun of us when we do and say "Etyroit men ne" ["That thing near you is thyroid" or "That thing of a person has a thyroid problem." ] $]^{35}$

At the time they cut my throat, I thought they-well, I don't really know, I really can't sing anymore, but I want to sing again, but now I can't...My voice won't go high anymore. Is that not from the contamination? ${ }^{36}$

It was a while after I had the surgery that I was able to sing again, and it wasn't just my voice, but it happened with the voices of all those who had surgery on their throats...I made sure to ask the doctors about it, though, to make sure they did a good job so that I would be able to sing again because that is my only talent—singing, and I needed to be able to sing again. ${ }^{37}$

\footnotetext{
${ }^{30}$ This is the reverse of auscultation, which is, according to Jonathan Sterne, a foundational practice for sonic modernity. The Audible Past: Origins of Sound Reproduction (Durham, NC: Duke University Press, 2003).

${ }^{31}$ David Morris, "Voice, Genre, and Moral Community," in Social Suffering, ed. Arthur Kleinman, Veena Das, and Margaret Lock (Berkeley: University of California Press, 1997), 29.

${ }^{32}$ For more information on the risks posed to men and women from exposure to radiation, see Arjun Makhijani, Brice Smith, and Michael C. Thorne, Science for Democratic Action 38, vol. 14, no. 4 (February 2007), http://www.ieer.org/sdafiles/14-4.pdf.

${ }^{33}$ For more information on permanent hoarseness and the other risks involved in thyroid surgery, see "Thyroid Surgery," American Thyroid Association, last modified 2012, http://www.thyroid.org/patients/brochures/ThyroidSurgery.pdf.

${ }^{34}$ Norio Kebenli, interview by Holly M. Barker, June 13, 2001. In Barker and Johnston, Rongelap, 170.

${ }^{35}$ Almira Matayoshi, interview by Holly M. Barker, June 13, 2001. In Barker and Johnston, Rongelap, 170.

${ }^{36}$ Ellen Boaz, interview by Holly M. Barker, June 13, 2001. In Barker and Johnston, Rongelap, 170.

${ }^{37}$ Lijon, conversation with author, October 2009.
} 
These statements expose the voice as a barometer of communal health, or social balance and gender complementarity. The silence of the specifically characteristic female vocal quality as an ability - the ability to sing as a soprano-also points to another devastating repercussion, another form of silencing, of the nuclear testing program: the severe impact of radiation on the reproductive capacity of women.

After the 1954 test, many Rongelapese women had multiple miscarriages, gave birth to severely deformed babies who would die shortly after the birth, and had to undergo hysterectomies. Silence functioned as a form of cultural censorship as many women, ashamed, humiliated, and fearing stigmatization, would conceal their pain. Further, the inability to produce offspring generates, in Jennifer Cognard-Black's terms, "the silence of lost generations and as a result, lost history." 38 The silence of the lost generations therefore becomes internalized by the women as theirs-their productions or reproductions that must stand in for the sounds of a healthy throat or a healthy, living child. Additionally, Marshallese society is matrilineal, and when women and their lineages are silenced and displaced, the entire social organization and generational cohesiveness of a community begins to unravel. Women attempt to pass down the legends, stories, and songs rooted in the land, but they say it is difficult without the geographical markers.

Such difficulties are compounded by the women's restricted access to their traditional means of healing. Customarily, a woman's vocal authority and musical abilities were essential to these healing practices, war and conflict resolution, and protecting indigenous knowledge. ${ }^{39}$ Irene J. Taafaki and Maria Kabua Fowler relate traditional feminine vocal authority to gender complementarity and land rights, which are central to Marshallese social structure:

In traditional Marshallese society, the ultimate voice was feminine, and inheritance of the land as well as power and authority rested with women. The female chief or lerooj, who was generally the sister of the chief held the ultimate authority; however the administration of affairs was deferred to men with the understanding that all matters were to be consulted upon. ${ }^{40}$

The aje drum is an important symbol and tool of women's customary power. During tattoo ceremonies, women would sit outside the tattoo hut, chanting, and drumming to mitigate the painful process and prompt the wounds to heal quickly. Similarly, the women chanted and beat the aje drum to encourage their men during battles that would determine the survival of a chiefly lineage. Dysrhythmia could throw the opponent off course.

Chants, drumming, and the associated physical gestures presented a gestural cartography of the sentient landscape and archived precious indigenous knowledge vital to survive. American Protestant missionaries first made contact with the Marshallese in the mid-nineteenth century, and they actively condemned traditional expressive culture in favor of teaching God's divine silence and hymnody in an aesthetic education aimed at redirecting the moral compass through aural conversion. These layers of colonial entanglements are resounded as contested values through the destabilized voices exemplified in the following statement made by a Rongelapese woman, Ellen Boaz:

\footnotetext{
${ }^{38}$ Jennifer Cognard-Black, “'I Said Nothing:' The Rhetoric of Silence and Gayle Jones’s 'Corregidora,” NWSA Fournal, Spring 2001: 42.

${ }^{39}$ See Jessica A. Schwartz, “Between Death and Life’: Mobility, War, and Marshallese Women's Songs of Survival.” in Women and Music 16 (2012).

${ }^{40}$ Traditional Medicine of the Marshall Islands: The Women, the Plants, the Treatments, ed. Irene J. Taafaki, Maria Kabua Fowler, and Randolph R. Thaman (Suva, Fiji: ISP Publications, 2006), 13.
} 
What can we say? Nothing-we don't know anything. We don't know a thing about medical care...[W]e don't know what procedures they did to us. What did they see? They just told us to go see a doctor, and then they tell us everything is okay. But us, we don't know, we don't know about medicine. We don't know how to examine the human body like they do. ${ }^{41}$

Ellen's statement puts pressure on epistemic dependency as a question of legitimacy, of value. She stresses that the global intervention into her particular culture is not commensurate with her ways of sensing, or perceiving the body. Framed in such a way, we can appreciate the epistemic orientations of Ellen's community on their terms and the difficulties in coming to terms with the prescriptions of doctors, given the radical alterity of the cultures. We can also appreciate the women's musical gestures that bring to light their terms as political, following Rancière's conviction that the relationship "proper" to politics is not that which exists between two or more subjects but, rather, one that exists between "two contradictory terms that define a subject." 42 These public musical performances are both counter-narratives to colonizing forces of the United States and strategic spaces of affective alliance, or an aesthetic connection that preserves an irreducible singularity, that produce new listening subjects by virtue of creating listening subjects (and not merely people who "hear" them as data, or do not hear them at all). Through these counter-narratives the Rongelapese preserve a survival mechanism they term ippān doon (being with, togetherness).

Ippān doon affords customary values of togetherness and conviviality as survival mechanisms. It is predicated on gender complementarity and is the prerequisite for the Marshallese definition of freedom as a collective shared space. Ippān doon affords experiential continuity against linguistic processes of fragmentary procedures such as removal from one's land, segregation in camps and on small islands, medical examinations that depended on isolation of bodily fluids and parts, and cultural debasement, which works at the core of colonial power relations.

\section{Nuclear Victims' and Survivors' Remembrance Day}

An important venue where the Rongelapese women share their stories with members beyond their community are Nuclear Victims' and Survivors' Remembrance Day (NVSRD) ceremonies. The events are held in Majuro every year on March 1, the anniversary of Castle Bravo, to pay respect to what has been lost due to nuclear damages. Often the ceremonies will last all day, and the Rongelapese women have consistently performed songs directly pertaining to the nuclear issues in additional to individual testimony from members of the community. Direct presentation of nuclear damages and indirect requests contribute to a nuanced politics of aesthetics, wherein tensions between the global and particular can be at play in one utterance. These spaces are of critical importance in examining musical performance and circulation as an alternative to, and perhaps critique of, the tribunal. ${ }^{43}$

Publicly, in diplomatic arenas such as speeches by the US ambassador during NVSRD, US politicians and representatives shift a focus from accountability to the benefits of US aid and economic assistance in the countries' partnership as "good friends." ${ }^{44}$ As an American, I was asked repeatedly, "How

\footnotetext{
${ }^{41}$ Barker, Bravo for the Marshallese, 56-57. Interview with Ellen Boaz (now deceased) by Barker. Emphasis added by author.

${ }^{42}$ Rancière, Dissensus, 29. Emphasis added by author.

${ }^{43}$ My thinking of the implications of musical performance as critique of the tribunal benefited from a comment by Nigel Hatton (University of California, Merced).

${ }^{44}$ The US ambassador mentioned the "world class programs" and "world class health care" that are now supposedly in the Marshall Islands courtesy of the United States in a speech at "Nuclear Victim's Remembrance Day," attended by the author on March 1, 2010.
} 
can our 'best friends' do this to us?" Without answers from the United States and a Nuclear Claims Tribunal that lacks funds from the United States to award compensation to nuclear "survivors and victims," these yearly events are of special importance to the Rongelapese women who prepare their musical performances weeks in advance, practicing for hours.

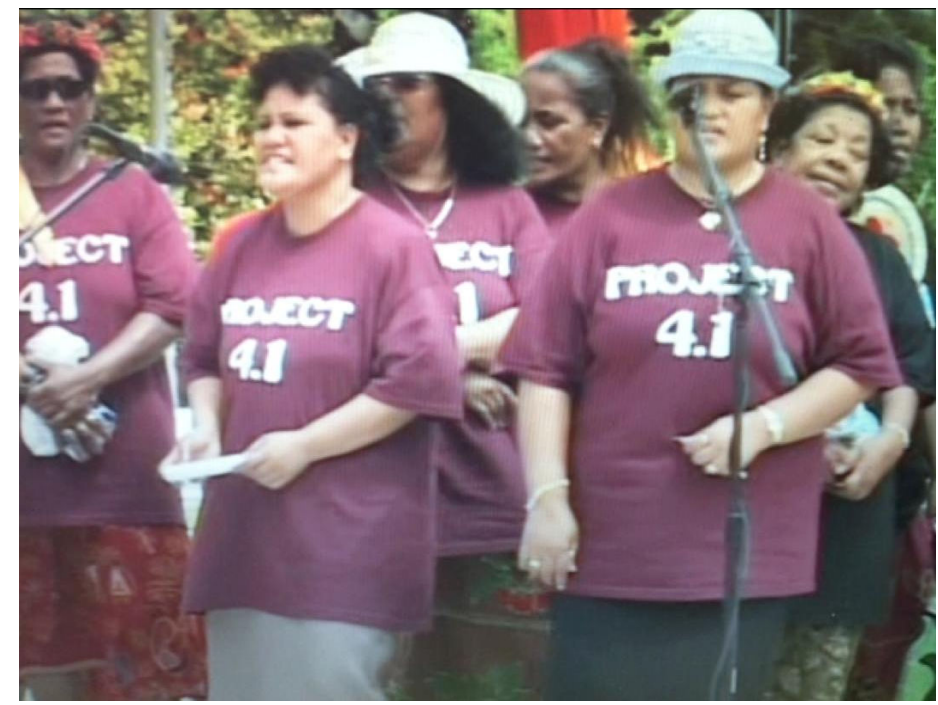

Figure 4. NVSRD 2004, Rongelapese women perform "177." (Still obtained from video at Mission Pacific Archive, Majuro, RMI.)

On March 1, 2004, the fiftieth anniversary of the Bravo test, in Majuro, approximately twenty-five Rongelapese men and women, mostly elderly women, stood in front of an audience of international dignitaries, local government officials, Japanese hibakusha, and residents of the Marshall Islands. Most all the women donned maroon or black shirts that read, in bold white, "Project 4.1." (Fig. 4). A man, dressed in black, stood in back of the women behind an electronic keyboard-the only musical accompaniment to the vocal performances. On the lawn of the Marshallese capital building, in Majuro, the Rongelapese women sang three songs, their anthem that recalls their homeland and their displacement, a song of solidarity with the other affected atolls, and finally, a song called "177." The title of the song, "177," refers to the section of the Compact of Free Association that outlines compensation for problems associated with the nuclear testing program. "177" is the United States' categorization of people from the irradiated "four atolls" of Bikini, Enewetak, Rongelap, and Utrik, even though the entire population of the Marshall Islands (and, in reality, the entire world) was exposed to radiation from the tests.

"177" was composed by a man, Tarines Abon. From the beginning of the song, "177" announces the presence of a 1950s America as foundational to and inextricable from the consequent issues that are presented lyrically. Recalling the soundscape of the displaced Rongelapese on Kwajalein Atoll, the unmistakable sonic reminiscence of a 1950s American country song à la 1950s Conway Twitty is uncanny. While on one level, the sensible space of the song is American, the other sensible space is thoroughly Marshallese, not least because of the language. The unintelligibility of the Marshallese language to American listeners mirrors the initial unintelligibility of the nuclear language the Rongelapese had to learn. The first verse is repeated twice, "All these thoughts of mine I give to you / These are the experiences I see 
in these days that don't belong to us." ${ }^{45}$ The song laments the unwanted inheritance. The Rongelapese reject their present day experiences resulting from the nuclear legacy as not being their own.

Video Example 3: “177,” Part I

View at: $\underline{\text { http://dx.doi.org/10.3998/mp.9460447.0006.101 }}$

Through almost identical melodic contours and an emphatic, heightened delivery, with voices strained on the melodic climax, "jojolāār" echoes "radiation." Radiation is insensible, and is conceptually unintelligible to the Marshallese. "Jojolāār" is the suffering of being abandoned and lost—a stranger to oneself and one's surroundings. It speaks to the uncanniness of not being in one's home and the unintelligibility of feeling estranged from oneself, signifying the "irreducible otherness of suffering." 46 Music here ruptures the status quo by "mak[ing] the [inaudible audible], and mak[ing] what was deemed to be the mere noise [(or metaphorical silence of noisiness)] of suffering bodies heard as a discourse concerning the "common' of the community." 47 Radiation is a common concern, as is its insensibility. By making "radiation" heard through its distinctive melismatic contour and connected by this melodic shape to another word that is sensible (as sound) and yet signifies the insensible, as Rancière notes, by removing itself from "the status quo" of exceptionality and silence, the Rongelapese articulate and "create a new form... of dissensual "commonsense." "48 Similarly, what is not yet "home," but what is home-_a peaceful place" exists in the world of appeals, a reaching out to the other, and this is the ethical gesture that defines the creation of the political space as a common and something in common.

\section{Video Example 4: “177,” Part II}

View at: $\underline{\text { http://dx.doi.org/10.3998/mp.9460447.0006.101 }}$

The final words of the chorus "Nomba en 177" underscore Rongelapese feelings of powerlessness as related to the fixity of being dehumanized by being identified as part of a number. This reflects back to the dialectical interplay between the materiality of sound and silence, to Project 4.1. Further, while only four Marshallese populations are included in 177, other populations were severely affected by radiation. The entire country struggles with the nuclear legacy and continued presence of the United States military. The temporal markings and tonal structure signifies the conclusion of the verse on the words "177." 177 is composed of experiences (sensory frames) that "don't belong to [the Rongelapese]" and the experiences that are formative for the Rongelapese (the song, the decision to share their voices). They share their ability to sing and their agency to question boundaries, limits, and the terms of their involvement.

Video Example 5: “177,” Part III

View at: $\underline{\text { http://dx.doi.org/10.3998/mp.9460447.0006.101 }}$

In the final verse, the declarative sentiment of the song fades into questioning ambivalences: "When will I be released from my sufferings that I still now do not understand?" Here the "irreducible

\footnotetext{
${ }^{45}$ I use my own transcriptions and translations of "177" along with the transcription and translation found in Barker, Bravo for the Marshallese, 95.

46 Morris, "Voice, Genre, and Moral Community, 29.

${ }^{47}$ Rancière, Dissensus, 139.

${ }^{48}$ Ibid.
} 
otherness of suffering" becomes twofold: neither the Americans nor the Marshallese can understand this suffering. The suffering, or the silence of suffering, becomes a constitutive othering. ${ }^{49}$ It separates the Marshallese from a present they feel is not theirs, yet it reaffirms what is only theirs: the suffering caused by the nuclear legacy and the responsibility to share their voices to evince experiences of what most of the world stills deems as "unthinkable." The final two questions, "Would you guide me and give me strength?" repeated, are indirect requests that transfer the dominant role and control from the questioner to the respondent. The Rongelapese relinquish not necessarily power to the respondent, to the Other (here, God, the United States, or both) through an aesthetic of indirect questioning, but they impress upon the respondent a responsibility to re-think the "unthinkable" and provide them with the answers necessary for their well-being.

\section{Voicing: the Urgency of Now}

Five years later, on March 1, 2009, Nuclear Victims' and Survivors' Remembrance Day, fifteen Rongelapese-all women-stood in front of memorial wreaths and paintings depicting the Bikinian exodus with a song composed entirely of questions. They faced the audience and sang "Kajjitok in ā ñan kwe kiō" ("These are my questions for you now"), which was composed by Lijon. "Kajjitok in ā ñan kwe kiō" was the song I heard most frequently during my time in the RMI, and it shares Rongelapese attempts to put pressure on the United States directly given the urgency of receiving answers to Rongelapese health problems. Lijon has watched as members of her community are "visited by doctors, issued a clean bill of health, and then wind up in the emergency room two weeks later." ${ }^{\text {50 }}$ Lijon told me that the impetus behind the song's composition just weeks earlier was in line with that of "177"- the continued unresponsiveness of the United States. At that time, representatives from the United States Department of Energy (DOE) visited the Republic of the Marshall Islands to meet with the RMI government. The Rongelapese women asked to attend the meeting, but their request was denied. Therefore, together with women from Utrik Atoll, they threw a party (kamōlo) for the DOE. Two days prior to the DOE party, Lijon decided to write "Kajjitok in a $\bar{n}$ nan kwe kiiō" and used the party, as a space of entertainment, to voice serious concerns in the song. Lijon penned lyrics of both testimony and appeal sharing a compilation of questions that continue to circulate among the Rongelapese community.

For Lijon, "Kajjitok in aō ñan kwe kiiō" shares a responsibility to give voice to the absolute silence, or voicelessness, of the dead-those who passed away and did not have the opportunity to share their suffering or receive answers from the United States. It also helps her to educate the younger generation on the difficulties they are facing and may encounter.

I wrote the song because of the questions that would come to my mind and also the minds of my sisters, some who have passed away....one time my little sister came to me and asked the same question, and when she asked this, I said in my heart that I will compose a song concerning these questions because she asked the same questions my older sisters, who are dead would often ask. ${ }^{51}$

The relatively strophic song begins with the lyrics, "these are my questions for you now / can you

\footnotetext{
${ }^{49}$ Morris, "Voice, Genre, and Moral Community," 29.

${ }^{50}$ Lijon, formal interview with author, 2009.

${ }^{51}$ Lijon MacDonald, informal discussion with author, October 27, 2009.
} 
help me find a way to untangle myself and my family from these things that hinder us?"52 The next line is, "Can you answer me?" Similar to the questions in "177," these formative indirect requests aestheticize a state of silence. Lijon writes regarding the stakes of the silence, "What is your opinion of the problems I have? / I have times when I cannot sleep peacefully / Can I please find meaning so I can find peace of mind ?/ Because I might go insane not knowing." For Lijon to remain sick or to "go insane" threatens her ability to write music or listen to others. The power remains with the United States to respond, to break such a state of silence, but without answers, the state of silence remains written into the song as negative space after each consequent "information-seeking" question in the chorus: "Why don't I have a dentist? / A doctor for my kidneys, my lungs, and my liver? / Will there be an end to taking pills? Aspirin, calcium, and gout medication? / Synthroid? Will these pills damage my kidneys, my brain, and my heart?"

The English words for doctor (takta), aspirin, calcium, thyroid (tyroit), kidney, and problem are used and transformed by the Marshallese language in the song. Within the overarching aestheticization of a state of continually imposed silence, the threading of borrowed and modified words that signify what was detrimentally imported (doctors, problems, medicines) into the lyrics recalls the inclusion and exclusion of the Rongelapese from the ownership of nuclear knowledge. These words amidst the other Marshallese words convey that the affective alliance is predicated upon strategic trust, which "is the sign of something ultimately unknowable." ${ }^{53}$ The unknowable is twofold: 1) the women's pain and the unanswered questions (the answers to these questions are not known by the Rongelapese, and it is unclear if they are known by the American doctors and scientists); and 2) the incommensurability of cultures with deep, meaningful legacies of articulation and corporeal attachments that exist outside aesthetic, affective alliances.

During the 2009 performance by members of the Rongelapese women's collective Iju in Ean, the Northern Star (a reference to their homeland, Rongelap) of "Kajjitok in aō nan kwe kiiō" on Nuclear Victims' and Survivors' Remembrance Day, we can hear the collective silence in the present marked as communal concern because it threatens vocal movement. Approximately three minutes into the performance, the volume of the song drops quickly. The vocal timbres become thin, squeaky, and some voices stop sounding altogether. Here, the compromised voices resonating from the compromised bodies of the women communicate, through their degenerated timbre, the incommunicability of their suffering. Their experiences of suffering that entailed the embarrassing and confusing doctor visits, the removal of their thyroids, the emotional pain of not knowing how to mend themselves, the social stigmatization, and the physical pain of being crippled by cancer cannot be articulated at the lexical level. Yet, with the shift in their vocal timbres, the audience senses something is off-kilter and begins clapping either as encouragement or out of respect for of the song's conclusion. The conductor turns to the audience, shakes her head, and points to her throat. "Ah, thyroid," she says and turns back to the women (Video 5).

This is not the metaphorical voicelessness of suffering. It is the actual voicelessness of suffering. Following Aaron Fox's statement that "the sound of the voice is the sound of social life," it is the unmaking of ippān doon, or the shared space of a collective voice as togetherness. ${ }^{54}$ The Marshallese word buro, or throat, which is akin to our version of "heart" as "the seat of the emotions," further evidences the importance of the voice in social life. The throat is the physical conduit for the voice, and the voice makes

\footnotetext{
${ }^{52}$ Translations aided by Lijon's granddaughter and Abacca Anjain-Maddison.

${ }^{53}$ Morris, "Voice, Genre, and Moral Community," 27.

${ }^{54}$ Aaron A. Fox, Real Country: Music and Language in Working-Class Culture (Durham and London: Duke University Press, 2004), 317.
} 
present one's emotions. Therefore, a damaged throat literally silences a person, denying her the ability to share her emotions with others. It becomes clear that even if the women had the potential for vocal empowerment as they once had, they would physically be incapable of engaging fully. The audience and singers hear the embodiment of the conditions for which they seek answers as an embodied knowledge in tension with the outside knowledge of the supposed authority to which they appeal- the West, the US.

\section{Video Example 6: "DOE”}

View at: $\underline{\text { http://dx.doi.org/10.3998/mp.9460447.0006.101 }}$

The women's voices come back from the momentary silence, which tells of the prolonged layers of silence, and the women collectively resist the roles they have been placed in as passive subjects, as numbers, and as victims. If freedom (anemkwōj) is responsibility for the shared sensible space of ippān doon, by hearing their voices fade, the Rongelapese, hear their freedom restrained. Their sensorial labor produces an understanding of the Other's voicings as a mechanism of silencing. And as they summon their voices once again, they regain control over the voicing of the terms of radiation. The Rongelapese women sing because they resolve to sound freedom and survival, not only for themselves but also for the future generations. We can see in the video how young children are learning these words and learning the mechanisms of musical inquiry as a matter of public appeal, or politics. The women look to the future to deal with their incorporation as "part of this whole nuclear craziness [and make heard] their bottom line...'We care about our children's future.' Because they know they are contaminated. They know that they'll be dying out soon. They are dying now-slowly." 55 Therefore, it is of the utmost importance that, in the ethical space of address, the Rongelapese women communicate that the time for redress is "now" (kiiō).

\section{Future Generations of Silences: What Cannot Be Said}

Jodikdik ñan Jodikdik ilo Ejmour (Youth to Youth in Health), a youth group based in Majuro, performed a poignant musical skit at NVSRD 2009 entitled "Emukat Eo Aō" ("My Moving"). Markers of loss pervade this present day "re-enactment" of the Rongelapese story. The skit conveys the ongoing devastation wrought by nuclear weaponry on the generational level. On stage left a sign "RMI" is held up to indicate that the dejected, downcast children are located in the Republic of the Marshall Islands-no longer a US Trust Territory. In the middle of the stage stands one lone doctor. While he is Marshallese, it is unclear if he is pretending to be American or one of the Marshallese health aides trained by American doctors. The lone figure that beckons to the children from the RMI side of the stage returns our attention to the isolation of the individual and the medical atomization of the body. Stage right is occupied by a handful of children happily playing catch with a basketball (Fig. 5).

\footnotetext{
${ }^{55}$ Darlene Keju-Johnson on the Rongelapese viewpoint of action for the benefit of the future, such as moves, establishing programs, etc., in Zohl dé Ishtar, Daughters of the Pacific (North Melbourne, Vic.: Spinnex Press, 1994), 36.
} 


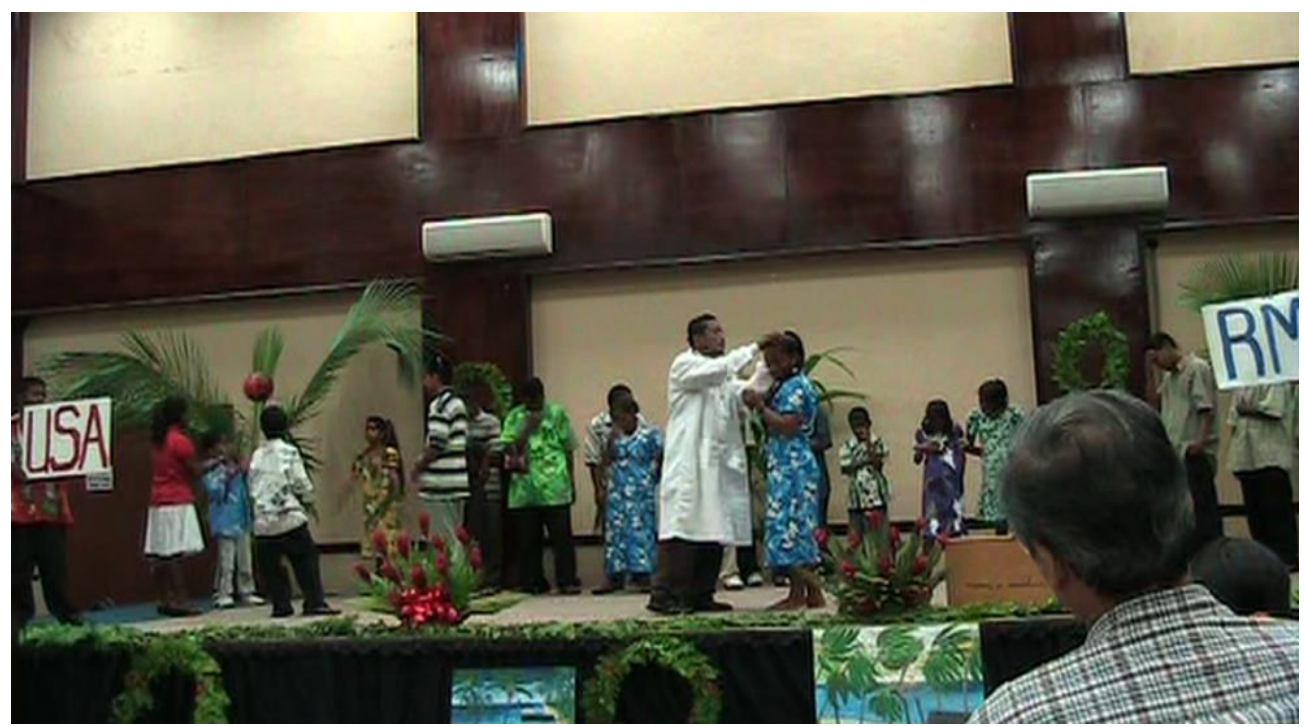

Figure 5. Jodikdik ñan Jodikdik ilo Ejmour perform "Emukat Eo Aō” (“My Moving”). (Still from video taken by author March 1, 2009.)

The sign "USA" is held up. Each child who is examined by the doctor never makes it to the USA, he or she is sent back, completely forlorn to the RMI side. The individuals on the RMI side cover their faces with their hands, blinding themselves to the reality of being trapped in a place where illnesses abound. The lyrics align the nuclear testing program with loss of health and culture. They are repeated to a slow keyboard accompaniment, "I am moving from the place where I grew up, from my roots. I am moving from my culture and the life on my homeland. Still, dangerous sicknesses emerge from the nuclear testing... and we live, but suffer from day to day." Clues to, and missed cures for, the problems presented lyrically are in what we cannot hear, they are in what is not being said.

A doctor stands in between healthy, happy children in the US. He encounters young girls and boys lined up, examines them, and then sends them back without saying a word. Let's take a closer look at how the doctor is listening. Rather than speak to the children, he listens with a stethoscope (a medical instrument). And, he listens to their hearts, often taking a quick gage of their pulse from the inside of their wrists. He listens through mediation of Western culture and its listening technologies, and he hears their hearts as barometer of health. Western culture locates the heart as the center of the soul and emotions, and science (or medicine) positions it as the center of our livelihood. As the seat of emotions, the throat, buro, is akin to our version of "heart," but it is also similar given that, for the Marshallese, the throat and the voice have been central to healing and survival as well.

\section{Health and Music}

The following appeared in the 2010 publication, The President's Cancer Panel Annual Report 20082009: "Of special concern, the US has not met its obligation to provide for ongoing health needs of the people of the Republic of the Marshall Islands resulting from radiation exposures they received during US nuclear weapons testing in the Pacific from 1946-1958." The latter statement is powerful, but it does not 
expose the enormity of what "health needs" are to the Marshallese. The disjuncture between what the United States considers "health" and what Rongelapese have needed for their health creates a silent excess of "illness" unthinkable to the United States, which is founded on incommensurable perceptions of the body, such as how the throat and voice are treated in experiences of sociality, and activistic, or affective components of healing. ${ }^{56}$ Jodikdik ñan Jodikdik ilo Ejmour provides music and a silent skit that demonstrates that, while sicknesses abound and these medical needs must be addressed, we keep looking, or listening, in the wrong place for answers. By emphasizing the space between the US and the RMI as the ethical relationship that exists between the doctor and the patient, it is important to listen to the modalities of sensorial, or affective investments, that are aestheticized as political whether the patient asks a question or remains visibly silent.

\section{Concluding Thoughts}

This article has stressed a focus on the aural and musical as important in discussions concerning the moral, ethical, and epistemic values that underlie the production and codification of nuclear knowledge precisely because of the conspicuous manipulation of silence that I have argued characterized the construction of global nuclear culture. More specifically, I have shown the ways in which Rongelapese women's musical activism, as the initiative to amplify the inscription of dual epistemic orientations to nuclear material on the exposed human, activates public spaces as political spaces. I then concluded with a gesture to the future as having its stakes in the voices of the present, which attest to the layers of silence and fragmentation.

To grasp the magnitude of the nuclear "unthinkable" as a justification for denial, withholding, and continued silencing of what is thinkable because it is sensible demands that indigenous knowledge be valued, and this means that we must legitimize musical expressions and their circulation as knowledge of the body, against traditional scientific narratives often upheld by the law of doctors and scientists. It demands that we make explicit what postcolonial theorist and political scientist Itty Abraham terms the "power of modern science in political terms, as ideology, particularly as a form of social legitimacy" that often discounts indigenous knowledge. ${ }^{57}$ To situate sound and science, music and silence as matters of the political reminds the world of the politicization of subjects that refuse to be silenced as "unthinkable." Day after day and year after year, the Rongelapese and other Marshallese communities circulate songs in and across their communities and share them with visitors who are open to listening and hearing at the same time.

\footnotetext{
${ }^{56}$ The burgeoning discipline of medical ethnomusicology addresses music, culture, and healing. For more information and a general overview, see The Oxford Handbook of Medical Ethnomusicology, ed. Benjamin D. Koen (Oxford: Oxford University Press, 2008).

${ }^{57}$ Itty Abraham, “The Contradictory Spaces of Post-Colonial Techno-Science," Economic and Political Weekly, January, 2006: 210.
} 


\section{References}

Abraham, Itty. "The Contradictory Spaces of Post-Colonial Techno-Science." Economic and Political Weekly, January 2006.

Alcalay, Glenn H. "Utrik Atoll: The Sociocultural Impact of Living in a Radioactive Environment (An Anthropological Assessment of the Consequential Damages from Bravo)," June 28, 2002.

Barker, Holly M. Bravo for the Marshallese: Regaining Control in a Post-Nuclear, Post-Colonial World. Belmont, CA: Wadsworth, 2004.

Barker, Holly M., and Barbara Rose Johnston. Consequential Damages of Nuclear War: The Rongelap Report. Walnut Creek, CA: Left Coast Press, 2008.

Cognard-Black, Jennifer. "I Said Nothing': The Rhetoric of Silence and Gayle Jones's Corregidora." NWSA Journal, Spring 2001, 40-60.

Cooke, Stephanie. In Mortal Hands: A Cautionary History of the Nuclear Age. Collingwood, Vic, Australia: Black Inc. Books, 2009.

dé Ishtar, Zohl. Daughters of the Pacific. North Melbourne, Vic.: Spinnex Press, 1994.

Eknilang, Lijon, and James Matayoshi. "Rongelap Survivors." In Life in the Republic of the Marshall Islands, edited by Anono Lieom Loeak, Veronica C. Kiluwe, and Linda Crowl, 123-32. University of the South Pacific Press, 2004.

Felman, Shoshana. "Benjamin’s Silence.” Critical Inquiry 25, no. 2 (1999): 201-34.

Fox, Aaron A. Real Country: Music and Language in Working-Class Culture. Durham and London: Duke University Press, 2004.

Hacker, Barton C. Elements of Controversy: The Atomic Energy Commission and Radiation Safety in Nuclear Weapons Testing 1947-1974. Berkeley and Los Angeles: University of California Press, 1994.

Johnson, Giff. "Rongelap return could happen in near future." RimajolOnline. Last modified March 26, 2012. http://www.rimajol.com/forums/viewtopic.php?t=5219.

Makhijani, Arjun, Brice Smith, and Michael C. Thorne. Science for Democratic Action 38, vol. 14, no. 4 (February 2007). http://www.ieer.org/sdafiles/14-4.pdf.

McEnaney, Laura. Militarization Meets Everyday Life in the Fifties. Princeton and Oxford: Princeton University Press, 2000.

Morris, David. "Voice, Genre, and Moral Community." In Social Suffering, edited by Arthur Kleinman, Veena Das, and Margaret Lock, 25-46. Berkeley: University of California Press, 1997.

Nancy, Jean-Luc. Listening. Translated by Charlotte Mandell. New York: Fordham University Press, 2007.

Newsday's "Fallout: Brookhaven's National Lab's Legacy in the Pacific." Directed by Thomas Maier and John Paraskevas. Newsday, 2009.

Nuclear Claims Tribunal. Memorandum of Decision and Order. Majuro, Republic of the Marshall Islands, April 17, 2001. http://www.nuclearclaimstribunal.com/rongelapfin.htm

"Nuclear Savage: The Islands of Secret Project 4.1." Directed by Adam Jonas Horowitz. Primordial Soup/Equatorial Films, 2012.

The Oxford Handbook of Medical Ethnomusicology. Edited by Benjamin D. Koen with Jacqueline Lloyd, Gregory Barz, and Karen Brummel-Smith (associate editors). Oxford: Oxford University Press, 2008. 
Rancière, Jacques. Dissensus: Politics and Aesthetics. Translated by Steven Corcoran. New York: Continuum, 2010.

Reducing Environmental Risk: What Can We Do Now? The President's Cancer Panel Annual Report 2008-2009. Edited by Susan H. Reuben for The President's Cancer Panel. Washington D.C.: U.S. Department of Health and Human Services, April 2010.

Schwartz, Jessica A. “'Between Death and Life': Mobility, War, and Marshallese Women's Songs of Survival." Women and Music 16 (2012).

Seremetakis, C. Nadia, ed. The Senses Still: Perception and Memory as Material Culture in Modernity. Chicago: University of Chicago Press, 1996.

Shannon, Claude. "Communication Theory of Secrecy Systems." Bell Systems Technical Journal 28, no. 4 (1949): 656-715.

Sterne, Jonathan. The Audible Past: Origins of Sound Reproduction. Durham, NC: Duke University Press, 2003.

“Thyroid Surgery." American Thyroid Association. Accessed May 20, 2012. http://www.thyroid.org/patients/brochures/ThyroidSurgery.pdf.

Todeschini, Maya.“The Bomb's Womb? Women and the Atom Bomb.” In Remaking a World: Violence, Social Suffering, and Recovery, edited by Veena Das, Arthur Kleinman, Margaret Lock, Mamphela Ramphele, and Pamela Reynolds, 102-56. Berkeley, Los Angeles, and London: University of California Press, 2001.

Traditional Medicine of the Marshall Islands: The Women, the Plants, the Treatments. Edited by Irene J. Taafaki, Maria Kabua Fowler, and Randolph R. Thaman. Suva, Fiji: ISP Publications, 2006.

"US States: Area and Ranking," Enchanted Learning.com. Accessed May 23, 2012. http://www.enchantedlearning.com/usa/states/area.shtml. 